\title{
DISKURSUS NASKH AYAT-AYAT TOLERANSI OLEH AYAT-AYAT PERANG DALAM AL-QUR'AN
}

\author{
Safrodin \\ Universitas Islam Negeri Walisongo Semarang - Indonesia \\ e-mail: safrodin@walisongo.ac.id
}

\begin{abstract}
This study intends to examine the question of the controversy of naskh on verses of tolerance with verses of war. These issues are (1) what is meant by verses of tolerance and verses of war in the Qur'an, and (2) what is the ulama's view of the dualism of the two types of verses? For this reason, this study uses the literature review method with hermeneutical-critical and comparative analysis. This study produces several things. Firstly, there are verses of tolerance in the Qur'an, which amount to 114 according to some scholars, or 140 verses according to other scholars, and verses of war against idolaters which number not less than 22 verses. Secondly, theoretically the scholars have discussed the assumption of dualism ( $t a^{\prime} \bar{a} r u d$ ) between verses of tolerance and verses of war in the study of the Qur'an. Islamic intellectuals such as Ibn Sallāmah, al-Shāmi, and Abdullah Bin Baz acknowledge the existence of ta'āruḍ, and therefore they also state that verses of tolerance have been replaced (mansūkhah) by verses of war as a way to resolve the conflict. Some other Islamic intellectuals such as Mustafa Zaid, Ahmad Ḥijāzi al-Saqā, and Yusuf Qardhāwi denied this assumption. On the basis of the study of siyāq al-kalām and munāsabah, in addition to the analysis of its historicity ( $a s b \bar{a} b$ al-nuzūl), these verses can be compromised, so that all the contexts are stated to apply. The views of the two types of scholars, hermeneutically, cannot be separated from the influence of the ideology surrounding each other's lives.
\end{abstract}

Abstrak: Kajian ini bermaksud mengkaji persoalan kontrovesi tentang naskh pada ayat-ayat toleransi dengan ayat-ayat perang. Persoalan tersebut meliputi: (1) apakah yang dimaksud dengan ayat-ayat toleransi dan ayat-ayat perang; dan (2) bagaimanakah pandangan ulama tentang dualisme kedua macam ayat tersebut? Untuk itu, kajian ini menggunakan metode kajian kepustakaan dengan analisis hermeneutis-kritis dan komparatif. Kajian ini menghasilkan dua temuan. Pertama, dalam al-Qur'an terdapat ayat-ayat toleran yang berjumlah 114 menurut sebagian ulama, atau 140 ayat menurut ulama lainnya, dan ayat-ayat tentang perintah perang terhadap orang-orang musyrik yang jumlahnya tidak kurang dari 22 buah ayat. Kedua, secara teoritis para ulama telah mendiskusikan asumsi dualisme (ta'äruḍ) antara ayat-ayat toleran dengan ayat perang dalam studi al-Qur'an. Intelektual Islam seperti Ibn Sallāmah, al-Shāmi, dan Abdullah Bin Baz mengakui eksistensi ta'āruḍ tersebut, dan sebab itu pula mereka menyatakan bahwa ayat-ayat toleran itu telah di-naskh (mansūkhah) oleh ayat perang sebagai cara untuk menyelesaikan pertentangan tersebut. Sebagian intelektual Islam lainnya seperti Mustafa Zaid, Ahmad Ḥijāzi al-Saqā, dan Yusuf 
Qardhāwi menafikan pertentangan tersebut. Atas dasar kajian siyāq al-kalām dan munāsabah ayat-ayat tersebut di samping analisis historisitasnya (asbāb alnuzūl), ayat-ayat tersebut -oleh kelompok ulama kedua ini- dapat dikompromikan, sehingga dinyatakan berlaku muhkam semua dengan konteksnya masingmasing. Pandangan dari kedua macam ulama tersebut, secara hermeneutikkritis, tidak dapat dilepaskan dari pengaruh ideologi yang melingkupi kehidupan masing-masing.

Keywords: naskh; verses of tolerance; verses of war

\section{A. Pendahuluan}

Stereotipe Islam sebagai agama pedang yang sarat dengan peperangan atau kekerasan telah lama berkembang di Barat. ${ }^{1}$ Meskipun terdapat sebagian kalangan Islamolog Barat yang menyadari bahwa pandangan tersebut tidak sepenuhnya benar, namun stereotipe tersebut masih belum bisa dihilangkan. Bantahan-bantahan teologis maupun historis memang telah banyak dikemukakan oleh kalangan intelektual Islam, tetapi eksistensi gerakan Islam garis keras ${ }^{2}$ di dunia Islam menjadi kontra produktif dengan penyangkalan tersebut. Hal ini seakan membuktikan bahwa Islam sering diekspresikan dalam dua wajah yang saling berlawanan, yakni wajah damai dan wajah perang. ${ }^{3}$

Al-Qur'an sendiri juga memuat ayat-ayat yang pada satu sisi tidak membolehkan memaksakan agama, memaafkan ketidaktahuan orang-orang kafir dan bahkan berbuat adil terhadap mereka, namun pada sisi lain juga

1Thomas W. Arnold, Preaching of Islam; History of the Propagation of Muslim Faith (New Delhi: Adam Publishers \& Distributors, 2002), 5: Lihat juga: Thomas W. Arnold, al-Da'wah ilā al-Islām; bahis fi Tārīkh Nasyr al-'Aqīdah al-Islāmiyyah (terj) (Mesir: Maktabah al-Nahẓah al-Miṣriyyah, 1970), 27.

2Banyak terma yang digunakan untuk menyebut Islam garis keras, yaitu Islam militan, Islam antiliberal, Islam skripturalis, Islam radikal, revivalisme Islam, ekstrimisme Islam dan yang paling populer, Islam fundamentalis. Terlepas dari ragam penamaannya, faham atau aliran ini memiliki perwatakan yang sama, yaitu gerakan yang menonjolkan aspek fundamentalismenya dengan menunjukkan watak militansinya hingga ekstrimitasnya Lihat pada: Umi Sumbulah, Konfigurasi Fundamentalisme Islam (Malang: UIN Press, 2009), 17-21.

${ }^{3}$ Asghar Ali Engineer menilai bahwa sebagian besar media di dunia memandang Islam identik dengan kekerasan (violence). Para sarjana atau jurnalis yang anti Islam atau yang memiliki beragam pemahaman yang dangkal itu mengutip beberapa ayat al-Qur'an untuk mendukung poin tersebut. Engineer telah mencatat bahwa media-media tersebut lebih tertarik pada reportase berita headline yang negatif dan sensasional mengenai gerakan-gerakan kekerasan dan pernyataan beberapa pemimpin muslim, sekalipun hanya sebagian kecil saja, yang menganjurkan jihad. Asghar Ali Engineer, Islam and Doctrines of Peace and Non-Violence", International Journal Ihya Ulum al-Din 3 no. 2 (2001): 121. Hal ini menunjukkan bahwa opini yang terbangun tentang Islam tersebut terkesan sangat tendensius dan tidak sepenuhnya objektif. 
mengandung ayat-ayat yang berisi perintah memerangi mereka. Hal ini menjelaskan bahwa dalam Islam memang terdapat potensi yang mendorong umat Islam untuk bersikap toleran terhadap orang-orang kafir, namun pada sisi lain terdapat juga potensi dorongan untuk berlaku tegas dan keras terhadap mereka, terutama bila ayat-ayat tersebut dipahami secara tekstualis semata dan terlepas dari konteks historisitasnya.

Kesan dualisme (ta'āruḍ) antara ayat-ayat toleransi dengan ayat-ayat qitāl ini telah memunculkan persoalan tersendiri di kalangan para ulama Islam, sehingga mereka mencoba mengurai persoalan tersebut dengan solusi yang diabsahkan dalam ilmu al-Qur'an. Intelektual Islam seperti Ibn Sallāmah (w. 337-410 H.), dan al-Shāmī lebih memilih menggunakan teori naskh dalam menyelesaikan persoalan dualisme tersebut. Sedangkan ulama lainnya seperti Muhammad Abduh (1849-1905 M.), Ahmad Ḥijāzī al-Saqā, dan Mustafa Zaid menyangkal solusi naskh sebagai cara untuk menyelesaikan persoalan pertentangan ( $t a$ 'arud ) tersebut. Oleh karenanya, kajian tentang "naskh ayatayat toleransi beragama dan ayat-ayat perang dalam al-Qur'an" ini menarik dilakukan.

\section{B. Ayat-ayat Toleransi dan Ayat-ayat Perang}

Ada sejumlah ayat dalam al-Qur'an yang menyerukan untuk bertindak "toleran" kepada orang-orang kafir, namun ada pula ayat yang memerintahkan untuk memerangi mereka. Ayat-ayat toleran itu jumlahnya berkisar 114 ayat versi Ibn al-'Arabi, dan berdasarkan penelusuran Musthafa Zaid sampai kisaran 140 ayat. $^{4}$

Ayat toleran tersebut oleh Mustafa Zaid diklasifikasikan menjadi enam kategori, yakni 1) ayat tentang penafian pemaksaan dalam beragama; 2) ayatayat sabar; 3) ayat-ayat tentang perintah berpaling dari orang-orang musyrik; 4) ayat yang memerintahkan untuk memaafkan orang-orang musyrik (ayat al-afw wa al-șafw); 5) ayat tentang perintah membalas keburukan atau menjawab bantahan dengan sesuatu yang lebih baik; dan 6) ayat yang berisi memperlakukan orang-orang kafir dengan perlakuan yang baik pula. ${ }^{5}$

4Mustafa Zaid, al-Naskh fi al-Qur'ān al-Karīm (Kairo: Dar al-Wafa, 1987), 508.

5 Zaid, 503.

JURNAL THEOLOGIA — Volume 30, No. 1, June 2019 
Ayat yang berisi tentang penafian paksaan dalam beragama misalnya terdapat pada al-Baqarah: 256, Yūnus: 99 dan al-Ghāsyiyah: 22. Ayat al-sabr antara lain tertuang dalam Āli 'Imran: 186, Tāha: 128-130, Șād: 16-17, Qāf: 39, alMuzammil: 10-14, al-Thūr: 48, al-Qalam: 48, al-Dahr: 24, al-Rūm: 60, al-Mu'min: 77, al-Nahl: 126-127, Yūnus: 109, al-Ahqāf: 35, dan al-Ma'ārij: 5. Ayat tentang berpaling dari orang-orang musyrik terdapat pada al-Nisā': 63, 81, al-An'ām: 106, al-Hijr: 94, al-Qasas: 55, al-Ṣaffat: 174-175, 178-179, Alif Lam Mim alSajdah: 30, al-Dukhān: 59, al-Najm: 29, dan al-Qamar: 6. Sedangkan ayat al-'afw wa al-shafh antara lain terdapat pada al-Māidah: 13, al-Hijr: 85, dan al-Zukhruf: 89.6

Ayat tentang perintah membalas keburukan dengan yang lebih baik antara lain terdapat pada al-Mu'minūn: 96, Hāmim al-Sajdah: 34, al-Baqarah: 83, alNahl: 125, al-Ankabūt: 46, dan al-Hajj: 68. Ayat lain yang berbicara tentang memperlakukan orang kafir dengan perlakuan yang baik antara lain terdapat pada al-Jātsiyah: 14, al-Mumtahanah: 8, Āli 'Imrān: 28, al-Nisā': 84, al-Nisā': 92, alAn'ām: 68 dan 108, al-Anfāl: 61, al-Hijr: 88, al-Nahl: 136, Maryam: 39, al-Nūr: 54, al-Furqān 63, al-Ahzāb: 48, Yāsin: 76, al-Zumar: 46, al-Syurā: 40, al-Zukhruf: 83, al-Qitāl: 4, al-Taghābun: 14, dan al-Tīn: 8.7

Pada sisi lain, terdapat sekitar 22 buah ayat ${ }^{8}$ yang memerintahkan umat Islam untuk memerangi orang-orang musyrik, dan salah satu di antaranya dikenal dengan ayat pedang (ayat al-saif). Ayat pedang ini, menurut pendapat yang paling shahih, adalah Surah al-Taubah: 5. ${ }^{9}$ Beberapa ayat lain yang memerintahkan perang adalah al-Taubah: 12, 13, 14, 29, 36, 123; al-Baqarah: 190, 191, 193, 216, 244, Āli Imrān: 167 dan al-Nisā': 76, 84, 89, 91; al-Anfal: 39, 65; al-Hujurāt: 9, al-Mumtahanah: 9, dan al-Hajj: 39.10 Di kalangan ulama, hanya dua ayat, yakni ayat pedang, al-Taubah: 5 dan ayat perintah memerangi orang musyrik secata totalitas pada al-Taubah: 36 yang sering dipandang sebagai alnasikh bagi ayat-ayat toleran.

\footnotetext{
${ }^{6}$ Muhammad Fu'ād 'Abd al-Bāqi, al-Mu'jam al-Mufahras li Alfāz al-Qur'ān al-Karīm (Kairo: Dār al-Hadīth, 1996), 644-645.

${ }^{7}$ Zaid, al-Naskh fi al-Qur'ān al-Karīm, 557-582.

8 'Abd al-Bāqi, al-Mu'jam al-Mufahras li Alfāz al-Qur'ān al-Karīm, 644-645.

${ }^{9}$ Zaid, al-Naskh fi al-Qur'ān al-Karīm, 504.

10`Abd al-Bāqi, al-Mu'jam al-Mufahras, 645.
} 


\section{Metode Penyelesaian Ta'ärud di antara Ayat-Ayat al-Qur'an}

Terdapat dua madzhab metode penyelesaian pertentangan (ta'ārự) antar dalil di kalangan para ulama, yakni metode ulama Hanafiyyah dan metode ulama Syāfi'iyyah. Kalangan intelektual Hanafiyyah ${ }^{11}$ menggunakan empat metode dalam menyelesaikan pertentangan tersebut. Pertama, metode naskh, yakni membatalkan hukum yang ada didasarkan pada adanya dalil yang datang kemudian yang mengandung hukum yang berbeda dengan hukum pertama. Kedua, metode tarjịh yaitu menguatkan salah satu di antara dua dalil yang bertentangan tersebut berdasarkan beberapa indikasi yang dapat mendukungnya. ${ }^{12}$

Ketiga, metode kompromi (al-jam'u wa al-taufiq),yakni mengumpulkan dalil-dalil yang bertentangan itu kemudian mengkompromikannya. Hasil kompromi dalil inilah yang diambil hukumnya. Metode keempat adalah tasāqut al-dalilain, yaitu menggugurkan kedua dalil yang bertentangan. Apabila cara ketiga di atas tidak bisa juga dilakukan oleh seorang mujtahid, maka ia boleh menggugurkan kedua dalil tersebut, dalam arti ia merujuk dalil lain yang tingkatannya di bawah derajat dalil yang bertentangan tersebut. ${ }^{13}$

Sedangkan ulama Syāfi'iyyah menggunakan metode tersebut di atas, namun dengan urutan yang berbeda. ${ }^{14}$ Metode yang mereka gunakan pertama adalah metode kompromi (al-jam' wa al-taufiq). Mereka berargumentasi dengan kaidah fiqh yang dikemukakan ulama Hanafiyyah, yaitu "mengamalkan kedua dalil itu lebih baik daripada meninggalkan salah satu diantaranya". Kedua adalah metode tarjị apabila pengkompromian kedua dalil itu tidak bisa dilakukan. Dalam hal ini mujtahid boleh menguatkan salah satu dalil berdasarkan dalil yang mendukungnya. Ketiga adalah metode naskh manakala kedua metode tersebut di atas belum bisa menyelesaikan pertentangan tersebut. Metode yang keempat adalah tasāqut al-dalīlain manakala ketiga metode tersebut tetap tidak bisa digunakan untuk menyelesaikan pertentangan itu. 15

\footnotetext{
11Wahbah al-Zuhalī, Ușūl al-Fiqh al-Islāmi (Beirut: Dār al-Fikr, 1986), 1176.

${ }^{12}$ Nasrun Haroen, Ushul Fiqh (Jakarta: Logos Wacana Imu, 1997), 173-180.

${ }^{13}$ Haroen, Ushul Fiqh, 173-180.

${ }^{14}$ al-Zuhalī, Ușūl al-Fiqh, 1182.

${ }^{15}$ Amir Syarifuddin, Ushul Fiqh I (Jakarta: Logos Wacana Ilmu, 1997), 200-210.
} 
Metode kompromi, menurut Khalaf, dapat dilakukan dengan dua cara. Pertama, ta'wìl, yakni mentakwilkan salah satu teks yang dianggap bertentangan itu dengan memalingkannya dari makna dhahir sehingga tidak lagi nampak pertentangan di antara keduanya. Kedua, memandang salah satu dari teks itu sebagai yang bersifat khusus (mukhassas) dan yang lainnya bersifat umum (al'ām), atau salah satunya terbatasi (muqayyad) dan yang lainnya bersifat mutlak, sehingga setiap teks tersebut dapat diamalkan sesuai dengan konteksnya masing-masing. ${ }^{16}$

Metode tarjịh dapat dilakukan manakala kedua teks yang dianggap bertentangan itu tidak dapat dikompromikan (al-jam') versi Syāfi'iyyah atau tidak dapat dilakukan naskh versi al-Hanafiyah. Metode tarjih ini dilakukan seorang mujtahid dengan cara mentarjih al-muhkam atas al-mufassar, mentarjih al-ibārah atas isyärah, mentarjih yang mengharamkan (al-muharrim) atas yang membolehkan (al-mubih), dan mentarjih hadits ahad dari sisi kedhabitan perawinya, keadilannya, kepakarannya dan lainnya. ${ }^{17}$

Sedangkan naskh, oleh para ulama', didefinisikan sebagai penggantian atau penghilangan hukum syara' dengan dalil syara',18 dan secara syar'i, naskh diartikan sebagai hilangnya hukum syarí dengan khitāb syar'i. Naskh dalam alQur'an, menurut para pendukungnya, dapat terjadi pada ayat-ayat yang mengandung muatan perintah (al-amr), larangan (al-nahy) atau hanya bersifat informatif (al-ikhbār). Terdapat tiga pandangan dalam hal ini. Pendapat pertama mengemukakan bahwa naskh hanya terjadi pada ayat-ayat perintah dan larangan saja. Pendapat kedua menyatakan naskh terjadi bukan saja pada ayatayat perintah dan larangan, melainkan juga ayat-ayat ikhbār yang mengesankan makna perintah atau larangan. Pandangan ketiga menyatakan bahwa naskh dapat terjadi baik pada ayat-ayat yang mengandung pengertian perintah, larangan, maupun pernyataan. ${ }^{19}$

${ }^{16}$ Abd al-Wahhāb Khalāf, 'Ilm Ușūl al-Fiqh (Kairo: Dar al-Kutub al-'Ilmiyyah, 1986), 230.

${ }^{17}$ al-Zuhalī, Ușūl al-Fiqh, 1177.

18Mannā’ al-Qattān, Mabāhitsfi 'Ulūm al-Qur'ān (Beirut: Muassasah al-Risālah, 1994), 232.

${ }^{19}$ Hibbatullāh Ibn Sallāmah, al-Nāsikh wa al-Mansūkh fi al-Qur'ān al-'Adzīm, (Damaskus: alYamāmah, 1987), 18. 


\section{Naskh Ayat-ayat Toleransi dan Ayat-ayat Perang}

Salah satu diskursus yang mengemuka dalam teori naskh al-Qur'an ini adalah naskh ayat-ayat toleransi atau biasa disebut ayat al-șaf̣h wa al-'afw oleh ayat-ayat perang ( $q i t a ̄ l)$. Beberapa intelektual muslim telah mengkajinya dalam karya-karya mereka, misalnya Hibatullāh bin Sallāmah (Ibn Sallāmah) dalam karyanya "al-nāsikh wa al-mansūkh fi al-Qur'ān al-'Azīm", al-Qadhi Ibn al-'Arabi dalam "al-nāsikh wa al-mansūkh fi al-Qur'ān al-'Ażīm" dan Mustafa Zaid dalam karyanya "al-nāsikh fi al-Qur'ān al-'Azīm, dirāsah tasyrīilyyah tārīkhiyyah naqdiyyah".

\section{Ada Pertentangan di Antara Keduanya}

Ibn Sallamah ${ }^{20}$ menyatakan bahwa surah al-Baqarah: 109 "fa'fū wa ișfahū" telah di-naskh oleh surah al-Taubah: 30 "Qātilū al-ladhīn lā yu'minūn bi Allāh wa lā bi al-yaum al-ākhir" hingga kalimat "ḥattā yu'tū al-jizyah 'an yad wahum șāghirūn". ${ }^{21}$ Hal yang sama juga dipandang terjadi pada surah Âli Imran: 20 "wa in tawallaw fa innamā 'alaik al-balāgh" dan surah al-Māidah: 99 "mā 'alā al-rasūl illā al-balāgh" telah di-naskh oleh ayat pedang (ayat al-saif) dalam surah alTaubah: 5 "faqtulū al-musyrikin haitsu wajadtumūhum". ${ }^{22}$ Ayat pedang tersebut oleh Ibn Sallamah dipandang telah me-naskh 124 ayat dalam al-Qur'an.

Ayat mansūkhah lainnya adalah al-An'am: 108. Ayat ini, menjelaskan bahwa Allah telah melarang umat Islam untuk mencaci maki orang-orang musyrik dari sudut pandang hukum lahirnya, namun -hemat Ibn Sallamah- hukum batinnya telah di-naskh, karena Allah telah memerintahkan untuk memerangi mereka. ${ }^{23}$ Surah al-Anfäl: 72-73 juga dinyatakan di-naskh oleh ayat pedang. Ayat ini menegaskan tentang adanya perjanjian di antara Nabi saw dan orang-orang Arab yang hidup saat itu untuk saling tolong menolong apabila dibutuhkan,

\footnotetext{
${ }^{20}$ Nama lengkap Ibn Sallamah adalah Hibbatullāh bin Sallamah Abu al-Qasim al-Baghdadi, salah seorang yang banyak memiliki pengetahuan tentang tafsir al-Qur'an. Ia berguru pada Abi al'Abbas al-Asham, sementara muridnya antara lain Syaikh al-Islam Abu Isma'il al-Anshari dan Abdul Wakhid al-Qusyairi. Ibn Sallamah lahir pada tahun 337 H. dan wafat pada 423 H. Lihat: Jalāl al-din 'Abd al-Raḥman bin Abi Bakr al-Suyūṭi, Tabaqāt al-Mufassirīn (Beirut Libanon: Dār al-Kutub al'Ilmiyyah, t.th.), 107.

${ }^{21}$ Ibn Sallāmah, al-Nāsikh wa al-Mansūkh fi al-Qur'ān al-Karīm, 23.

22Ibn Sallāmah, 46, 64.

23Ibn Sallāmah, 46 \& 64.
}

JURNAL THEOLOGIA — Volume 30, No. 1, June 2019 
namun ayat ini menjadi di-naskh oleh ayat pedang. ${ }^{24}$ Surah Yūnus: 20, 41, 46, 99, 102,108 , dan 109, juga merupakan ayat mansūkhah oleh ayat pedang dalam alTaubah, Hūd: 12 dan 121 dan al-Ra'd: 40".25

Sejumlah ayat yang dinyatakan mansūkhah oleh ayat pedang adalah al-Hijr: 3, 85, 88, 89, dan 94,", al-Nahl: 83 dan 128, Banī Isrāil: 54, Maryam: 39, 75 dan 84, Țaha: 130, al-Ḥajj: 49, al-Mu'minūn: 54, al-Nūr: 54, al-Qașas: 55, kecuali al'Ankabūt: 46 yang di-naskh dengan ayat perang, al-Taubah: 29, al-Ankabūt: 50, al-Rūm: 60, al-Sajdah: 30, al-Ahzāb: 48, Saba': 25 al-Malāikah: 23, al-Ṣāffat: 178179 dan Ṣād: 70, 88.26

Beberapa ayat lain yang juga dianggap mansūkhah oleh ayat pedang adalah al-Zumar: 3, 15, 39, 40, 41, 46, al-Mu'min: 12, Fușṣilat: 34, al-Shūrā: 6, 15 terakhir, 48, al-Zukhrūf: 83, 89, al-Dukhān: 59; al-Jāthiyah: 14; al-Ahqāf: 35; Muhammad: 4; Qāf: 39, 45; al-Ṭūr: 31, 48, 45; al-Najm: 29; al-Qamar: 6, alMumtahanah: 8 dan 9, al-Qalam: 44, 38; al-Ma'ārij: 5, 42; al-Muzzammil: 10; alMuddathir: 11; al-Dahr: 8, 24; al-Ṭāriq: 17; al-Ghāsyiyah: 22-23; al-Tīn: 8; dan kalimat terakhir dari ayat 6 surah al-Kāfirun "wa liya din" ${ }^{27}$

Ibn Sallāmah menyatakan secara tegas bahwa ayat-ayat toleran atau yang disebut ayat al-șafw wa al-'afw seperti dalam al-Baqarah: 109 juga mansūkhah oleh ayat qital dalam al-Taubah: 30. Ayat șafh yang berisi tentang anjuran memaafkan kepada orang-orang musyrik waktu itu di-naskh dengan ayat yang memerintahkan untuk memerangi orang-orang yang tidak beriman kepada Allah Swt dan hari akhir. Hal yang sama terjadi pula pada al-Baqarah: 139 yang berisi anjuran untuk bersikap toleran dengan menyatakan "bagi kami amalamal kami, dan bagi kalian amal-amal kalian sendiri" di-naskh oleh ayat pedang pada surah al-Taubah: 6 yang secara tekstual mengandung perintah memerangi orang-orang musyrik secara keseluruhan. ${ }^{28}$

Ketetapan status naskh ayat-ayat toleran tersebut karena dipandang bertentangan (ta'ārud) dengan ayat al-saif atau ayat al-qitāl, dan cara penye-

\footnotetext{
${ }^{24}$ Ibn Sallāmah, 74.

25Ibn Sallāmah, 78-83.

26Ibn Sallāmah, 84-105.

27Ibn Sallāmah, 106-139.

28Ibn Sallāmah, 23.
} 
lesaiannya, dalam pandangan Ibn Sallamah, dengan menggunakan teori alnaskh. Karena ayat-ayat toleran dianggap turun lebih dulu, maka ia dihapus dan digantikan (mansūkhah) dengan ayat pedang atau ayat perang. Dalam hal ini, Ibn Sallamah nampaknya memahami konsep naskh sebagai penghilangan hukum syara' (raf al-hukm) dengan dalil syara'. Dengan demikian, hukum mansukh sudah tidak lagi berlaku, karena hukum nāsikh dianggap final dan paripurna, sementara hukum mansūkh yang berlaku sebelum datangnya ayat nāsikh, hanya dianggap sebagai penundaan berlakunya hukum nāsikh, karena tuntutan situasi dan kondisi waktu itu yang bersifat tentatif.

Pandangan tersebut juga dikuatkan oleh pendapat al-Shami. Menurutnya, kronologi hukum perang dalam al-Qur'an ditetapkan dalam tiga tahapan. Pertama, perang pada mulanya diharamkan kepada Nabi dan umatnya. Kedua, perang kemudian diizinkan bagi mereka yang telah diusir dan diperangi. ${ }^{29}$ Ketiga, perang diperintahkan dan menjadi wajib bagi Nabi dan umatnya namun masih terbatas, yakni terhadap orang-orang musyrik yang memerangi mereka; dan keempat perang menjadi wajib dilakukan secara lebih luas, yakni terhadap seluruh umat musyrik tanpa terkecuali sehingga agama semuanya milik Allah. ${ }^{30}$

Pendapat di atas didasarkan pada argumentasi historis yang melingkupi perjalanan umat Islam waktu itu, di mana Muhammad saw selama tiga belas tahun telah menyampaikan risalah Islam kepada bangsa Arab di Makkah dan sekitarnya di bawah tekanan dan ancaman kaum kafir Quraisy. Banyak penderitaan yang dialami Nabi dan para pengikutnya dengan beragam cara dan bentuk. Setiap kali Nabi sedih melihat keadaan kaumnya, Allah selalu mengingatkannya untuk bersifat tabah dan sabar hingga beliau dan umatnya hijrah ke Madinah. ${ }^{31}$

Allah lalu mengizinkan (al-Hajj: 39) Nabi dan umatnya memerangi orangorang musyrik yang telah lama memerangi mereka, mengusir mereka dari tanah kelahiran dan tempat tinggalnya dan berbuat aniaya terhadap mereka

${ }^{29}$ Ayat tentang izin berperang ini secara kronologis merupakan ayat pertama kali diturunkan berkaitan dengan peperangan dalam Islam, sebagaimana riwayat Imam al-Turmudhi, al-Nasa'i, Ibn Majah dan Ibn Hiban.

30Muhammad bin Yusuf al-Sālihī al-Shāmī, Subūl al-Hudā wa al-Rashād fi Sirah khair al-Ibād (Beirut-Libanon: Dār al-Kutub al-'Ilmiyyah, 1993), 5.

${ }^{31}$ al-Shāmī, 5. 
setelah beliau dan umatnya telah berubah menjadi komunitas yang kuat secara politik maupun sosial. Izin berperang pada tahapan ini belum menjadi kewajiban. ${ }^{32}$ Kewajiban berperang baru diperintahkan kepada Nabi saw dan umatnya dalam al-Baqarah: 190.33

Pada tahapan berikutnya, kewajiban berperang menjadi lebih luas karena yang diperangi bukan semata orang-orang musyrik yang memerangi umat Islam waktu itu, melainkan seluruh umat musyrik sebagaimana mereka memerangi umat Islam semuanya. Seruan perang yang lebih umum ini tertera dalam alTaubah: 36 dan al-Baqarah: 216. Ketetapan inilah yang oleh sebagian ulama tafsir dipandang sebagai jalan naskh ayat-ayat qitāl atas ayat-ayat toleran. Penafsiran tentang perintah perang yang terakhir ini mengesankan bahwa perang dalam Islam tidak lagi bersifat defensif (al-qitāl al-difāí), melainkan lebih bersifat ofensif (al-qitāl al-talabi), yakni memerangi setiap kekufuran dan kemusyrikan di muka bumi ini.

Abdullah bin Baz juga sependapat dengan premis di atas. Ia bahkan secara eksplisit membenarkan dan menyetujui jihad ofensif (jihād talabi) serta meyakini bahwa ayat saif-lah, pada dasarnya, yang diberlakukan, karena ayat ini yang paling akhir diturunkan sehubungan dengan syari'at perang. Ia menyetujui bahwa ayat saif menghapus ayat-ayat sebelumnya yang berisi ayat-ayat toleran. Namun demikian, dalam hal tertentu ia memahami juga makna naskh sebagai penundaan, bukan penghapusan hukum. Karena, di tempat lain ia menguatkan pendapat Ibnu Taimiyah yang menyatakan ayat sabar itu berlaku lagi dalam keadaan jika kaum Muslim dalam keadaan lemah. ${ }^{34}$ Sekalipun demikian, pandangannya tentang ayat-ayat pedang itu tetap saja mengesankan adanya pembolehan pemaksaan agama dalam missi jihād țalabi tersebut.

Terkait dengan sasaran jihad, Abdullah Bin Baz (1909-1999M.)35 menyatakan bahwa semua orang non-Muslim menjadi sasaran jihad, baik jihad

32al-Shāmī, 4.

33al-Shāmī, 5.

${ }^{34}$ Ali Trigiatno, "Penyelesaian Ayat-ayat Damai dan Ayat Pedang dalam al-Qur'an", Jurnal Penelitian STAIN Pekalongan 9, no. 2 (2012), 273.

${ }^{35}$ Abdullah bin Baz lahir di Riyadh Arab Saudi pada tahun 1909 dan meninggal dunia pada tahun 1999. Ia adalah salah seorang ulama kontemporer yang ahli di bidang sains Hadits, Aqidah dan Fiqh. Ia pernah menjabat sebagai mufti kerajaan Saudi Arabia, kepala Liga Muslim Dunia, Rektor Universitas Islam Madinah, anggota Hai'ah Kibar al-'Ulama' dan ketua Dewan Riset Ilmu dan Fatwa. 
țalabi maupun jihad difā'i, kecuali orang-orang yang membayar jizyah (pajak). Menurutnya, maksud dilakukannya jihad tidak lepas dari dua tujuan jenis jihad, yakni jihad țalab dan jihad difā'. Kedua jenis jihad ini memiliki maksud dan tujuan menyampaikan dan mendakwahkan agama Allah mengeluarkan umat manusia dari kegelapan kepada petunjuk, meninggikan agama-Nya di muka bumi, dan agar supaya semua agama hanya milik-Nya semata. ${ }^{36}$

\section{Tidak Ada Pertentangan di Antara Keduanya}

Berbeda dengan pandangan yang mengakui penghapusan ayat-ayat toleran oleh ayat pedang sebagaimana tersebut di atas, Mustafa Zaid sepenuhnya menolak pandangan yang mengakui adanya pertentangan ( $t a^{\prime} a \bar{r} r u d$ ) di antara kedua ayat tersebut. Ia menegaskan tidak ada petentangan ( $t a$ 'âruḍ) antara ayatayat toleran dengan ayat-ayat pedang (ayat al-saif), sehingga tidak diperlukan klaim naskh di antara keduanya. ${ }^{37}$ Bantahan itu ia buktikan dengan menganalisis ayat-ayat toleran maupun ayat perang dan pedang itu, baik dari perspektif sosio-historisnya maupun aspek semantiknya.

Perintah perang dalam Surah al-Taubah: 5, baginya, bukan ditujukan untuk orang-orang musyrik secara umum, melainkan orang-orang musyrik dengan karakter tertentu dan pada masa tertentu. ${ }^{38}$ Orang-orang musyrik dimaksud adalah orang-orang musyrik yang memusuhi Nabi saw. dan umatnya, menghalang-menghalangi kebebasan dakwahnya dan mengusir umat Islam dari tanah kelahirannya, dan bahkan secara licik mengingkari perjanjian yang telah disepakati bersama. Mereka adalah orang-orang musyrik dengan sejarah panjang penentangan dan penindasan terhadap umat Islam sejak di Makkah hingga Madinah. Mereka mengawali memerangi Islam terlebih dulu dalam pertempuran Badar hingga pertempuran lainnya. Perang dalam konteks ini lebih bersifat defensif, sebagai upaya menghilangkan penindasan agama, dan

Lihat: Amin Farih, Analisis Pemikiran Abdullah bin Baz dan Sayyid Muhammad al-Maliky; Mencari Titik Kesepakatan Sunny dan Wahaby Melalui Metodologi Istinbath Hukum Islam (Semarang: LP2M IAIN Walisongo, 2014), 82-83.

36Trigiatno, “Penyelesaian Ayat-ayat Damai dan Ayat Pedang dalam al-Qur'an”, 273.

37Zaid, al-Naskh fi al-Qur'ān al-Karīm, 506.

38Zaid, 506.

JURNAL THEOLOGIA — Volume 30, No. 1, June 2019 
sama sekali tidak bertujuan untuk mengislamkan orang secara paksa melalui pedang. 39

Perang tersebut, menurutnya, hanya berlaku terhadap orang-orang musyrik maupun kafir yang memiliki karakter tersebut sebagaimana tergambar dalam konteks orang-orang musyrik yang memerangi Nabi saw dan umat Islam waktu itu. Dengan begitu, al-Baqarah: 256 yang telah menegaskan konsep tiada paksaan dalam beragama tetap berlaku, dan bahkan kandungannya juga dikukuhkan dalam al-Yunus: 99, yang menjelaskan bahwa memaksakan manusia untuk menjad muslim semua merupakan hal yang mustahil. ${ }^{40}$

Lebih lanjut Zaid menguraikan konteks sosio historis terma "al-musyrikin" dalam ayat pedang itu. Menurutnya, al-Taubah: 5 memang berisi perintah untuk memerangi orang-orang musyrik yang ditemui di manapun dan menawan mereka yang tidak terbunuh, namun pertanyaannya adalah orang musyrik yang mana yang dimaksud ayat itu. Orang-orang musyrik yang dimaksud dalam ayat pedang tersebut adalah kelompok musyrik tertentu yang telah menyepakati perjanjian bersama Nabi saw waktu itu, namun mereka mengingkari dan tidak menepatinya serta melahirkan permusuhan dengannya. Orang musyrik macam itulah yang diizinkan untuk diperangi, apabila mereka tidak bertaubat dari kekufuran, tidak beriman kepada Allah Swt. sebagai Tuhan yang Maha Esa dan mengakui Muhammad sebagai Nabi dan Rasul. ${ }^{41}$

Terma "al-musyrikin" dalam ayat itu adalah orang-orang musyrik yang memusuhi Islam dan Nabinya, bukan orang-orang musyrik secara umum, karena pada ayat setelahnya disebutkan bahwa orang-orang musyrik yang menepati perjanjiannya dan tidak melahirkan permusuhan dengan Islam menjadi pengecualian untuk tidak diperangi dan dijamin keamananya hingga waktu perjanjian itu selesai. ${ }^{42}$ Mereka yang diperangi adalah para pemimpin kekafiran yang memiliki beberapa karakter, yakni 1) menistakan agama Allah dan menghalang-halangi orang lain dari jalan-Nya, 2) mengingkari perjanjiannya bersama Rasulullah, 3) melahirkan permusuhannya terhadapnya, 4) bersifat hipokrit terhadapnya dan orang mukmin, nampak rela ucapannya

\footnotetext{
${ }^{39}$ Zaid, 506.

40Zaid, 106.

41Zaid, 504.

42 Zaid.
} 
padahal hatinya membangkang, 5) mengingkari janji dan sumpah mereka, 6) bercita-cita mengusir Rasul, 7) memulai memerangi orang-orang mukmin, dan 8) selalu menanti kesempatan yang tepat untuk merusak perjanjian mereka. Orang-orang musyrik dengan segenap atribut itulah yang diperintahkan dalam ayat itu untuk diperangi sebagai siksa dari Allah bagi mereka. ${ }^{43}$

Dengan demikian, tujuan memerangi mereka bukanlah untuk memaksa mereka agar memeluk Islam dengan kekuatan pedang sama sekali. Pandangan ini diperkuat sendiri oleh ayat berikutnya "wa in ahad min al-musyrikin istajāraka Allāh fa ajirhu hattā yasma' kalām Allāh, tsumma aiblighhu ma'manah, dzālika bi annahum qaum la ya'lamūn". Pada ayat ini terdapat perintah Allah Swt. untuk menyelamatkan orang musyrik yang memohon perlindungan, mengajaknya untuk beriman kepada Allah, dan menerangkan kepadanya kebaikan yang terdapat dalam keimanan itu. Apabila setelah itu, ia tetap dalam kesesatan dan kekufurannya dan meminta Rasulullah mengantarkannya sampai tempat yang aman, maka Rasul berkewajiban memenuhi permintaannya dan menjamin keamanannya hingga tempat tujuan. ${ }^{44}$ Ayat tersebut di atas dengan tegas, oleh Zaid, dipandang meniadakan segala bentuk dan jenis pemaksaan agama dalam Islam.

Argumentasi lain yang dijadikan dasar bagi pernyataan itu adalah Surah alBaqarah: 256 "la ikrāh fi al-dìn qad tabayyan al-rusyd min al-ghay" dan Yunus: 99 "wa law syā'a rabbuk la'āman man fi al-ardh kulluhum jamīa, a fa anta tukrih alnās hattā yakunu mu'minin". Kedua ayat ini menegaskan tiada pemaksaan agama dalam Islam, dan tidak mungkin Nabi dapat memaksa seluruh manusia untuk menjadi mukmin. ${ }^{45}$

Atas dasar itulah, Mustafa Zaid menyatakan bahwa perang dalam Islam disyariatkan semata-mata untuk menjaga keamanan dan kebebasan para da'i dalam menyampaikan dakwah Islam dan menolak kesalahan pandangan tentang aqidahnya dengan logika yang sehat dan argumentasi yang meyakinkan. Para pemimpin kafirlah yang harus diperangi manakala mereka berupaya dengan segenap kekuatan dan daya untuk menghalang-halangi dakwah Islam

43Zaid, 506.

${ }^{44}$ Zaid.

45Zaid, 507. 
dan memusuhi serta memerangi orang-orang mukmin. Peperangan menjadi tidak diperlukan manakala keadaan terjamin secara kondusif baik keamanan maupun kebebasannya bagi dakwah Islam. Karena Islam, di saat demikian, akan menjadi petunjuk dengan cahayannya bagi setiap orang yang tersesat, dan setiap kebatilan perbuatan syirik kepada Allah akan terungkap dengan jelas bagi setiap orang musyrik, sehingga tidak akan tetap pada kesyirikan kecuali mereka yang ingkar, durhaka dan sombong terhadap kebenaran. ${ }^{46}$

Yang dipersoalkan oleh Zaid adalah bagaimana mungkin ayat-ayat ini dinyatakan mansūkhah dengan ayat pedang, dan yang lebih mengherankannya adalah pernyataan Ibn al-'Arabi bahwa ayat pedang (ayah al-saif) tersebut menaskh 114 ayat, termasuk ayat yang belakangan di-naskh oleh ayat awalnya. Penelusuran Zaid sendiri menemukan bahwa ayat-ayat al-Qur'an yang dianggap mansūkhah oleh ayat pedang itu ternyata berjumlah hingga 140 ayat.

Mustafa Zaid mengajukan beberapa argumentasi untuk mendukung pandangan tentang tidak adanya naskh ayat-ayat "toleransi" dengan ayat pedang atau ayat perang. Pertama, terma "al-fitnah" pada al-Baqarah: 193 pada dasarnya bermakna ujian atau cobaan (al-ibtilä) dan (al-ikhtibār). Beberapa penafsir seperti al-Tabari, dan Ibn Katsir memaknai kata tersebut dengan "syirk". Sedangkan Ibn al-'Arabi menafsirkan kata "fitnah" dengan "kekufuran" dengan dalil firman Allah "wa al-fitnah ashadd min al-qatl", yakni kekufuran karena tatkala mereka kafir di masjid al-Haram, menyembah berhala di dalamnya dan menyiksa pemeluk Islam agar mereka kembali murtad pada agama mereka terdahulu, maka semua itu merupakan fitnah dalam pengertian dasarnya, yakni ujian dan cobaan..$^{47}$

Dalam hal ini, kufur disebut fitnah karena ujung dari ujian ini adalah kekufuran, sehingga peperangan tersebut disyariatkan dalam rangka untuk menangkal dan mencegah fitnah tersebut. Tujuan lainnya setelah itu adalah agar agama menjadi milik Allah. Terma "al-din" dalam konteks ini berarti ketaatan dan keteraturan. Dengan begitu, ayat perang tersebut memberikan pengertian bahwa yang diperangi adalah kalangan musyrik Arab yang melahirkan permusuhan dengan Islam, bukan orang-orang kafir yang membuat perjanjian

46Zaid.

47Zaid, 510. 
damai dengan baik. Oleh karenanya, tujuan dari peperangan itu bukanlah untuk memaksakan agama Islam kepada mereka dengan kekuatan pedang, melainkan lebih untuk menciptakan dan memelihara stabilitas dan keteraturan Islam dan masyarakatnya, agar tidak ada penghalang antara para pendakwah Islam dengan yang didakwahinya dan supaya tidak ada fitnah bagi umat muslim pada agamanya. ${ }^{48}$

Dengan demikian, peperangan dalam Islam disyari'atkan bukan untuk memaksakan agama, sehingga tidaklah dapat dibenarkan klaim adanya naskh pada ayat "lā ikrāh fi al-dīn" karena ayat itu menunjukkan pengertian yang umum yang menunjuk pada peniadaan paksaan dalam beragama. ${ }^{49}$ Selain itu, ayat tersebut berbentuk kalimat informatif (kalām khabar) yang tidak menerima naskh, dan kalaupun ayat dimaksudkan untuk suatu larangan (alnahy), maka larangan itu pun sama sekali tidak bertentangan dengan perintah untuk berperang melawan orang-orang musyrik, karena tujuan peperangan itu bukan untuk memaksakan agama. ${ }^{50}$ Jadi, tidak ada relevansi dan korelasi perintah memerangi orang-orang musyrik dengan pemaksaan agama, baik dari sudut semantik maupun historis.

Meskipun ayat tersebut, lanjut Zaid, dipandang berlaku khusus karena turun berkaitan dengan ahlu kitab yang mengakui pajak atau sebab khusus yang lain, tetapi pijakan yang digunakan pada ayat ini adalah teori "al-ibrah bi 'umūm al-laf̧̌, là bi khușūs al-sabab", di mana kata "ikrāh" yang digunakan dalam ayat tersebut itu bersifat umum "ām" untuk menafikan segala jenis pemaksaan dalam beragama. Ayat itu telah menetapkan sebuah prinsip dasar dalam beragama yang tidak layak untuk di-naskh, karena ia merupakan prinsip dasar dalam beragama yang telah lama menjamin keagungan dan kemulyaan Islam

48Zaid, 511.

${ }^{49}$ Muhammad Chirzin menguatkan pandangan tersebut dengan menyatakan bahwa al-Qur'an menuturkan beberapa kelompok agama dan membimbing tata pergaulan antar umat beragama. Keragaman agama meniscayakan umat Islam untuk mengakui dan menghormati agama-agama lainnya, di samping mereka juga meyakini kebebasan atau tiada paksaan dalam beragama. Sekalipun demikian, menurutnya, meyakini keragaman agama dan keberagamaan bukan berarti menganggap semua agama sama dan benar. Lihat: Muhammad Chirzin, "Keanekaragaman dalam alQur'an”, Tsaqafah Jurnal Peradaban Islam 7, no. 1 (2011), 57. Jadi, ada eksklusivitas dalam keyakinan agamanya sendiri, namun tetap bersikap inklusif dalam pergaulan sosial sebagai perwujudan kasih sayang dan penghormatan berdasarkan nilai-nilai kemanusiaan.

50Zaid, al-Naskh fi al-Qur'an al-Karim, 510.

JURNAL THEOLOGIA — Volume 30, No. 1, June 2019 
dalam sejarah panjangnya, yakni agama yang telah menjamin kebebasan dan kemerdekaan individu. ${ }^{51}$

Intelektual Islam lain yang sependapat dengan Mustafa Zaid adalah Ahmad Hijazi al-Saqa. Ia menolak dengan tegas eksistensi naskh ayat-ayat toleran oleh ayat-ayat pedang (ayat al-saif). Al-Saqa ketika menafsirkan al-Baqarah: 10952, menjelaskan bahwa pendapat yang menyatakan ayat ini di-naskh oleh ayat pedang merupakan pandangan yang jauh dari kenyataan, karena kedua ayat tersebut memiliki objek pembicaraan yang berbeda, yakni yang satu berbicara khusus mengenai ahli kitab dan yang lainnya berbicara tentang orang-orang kafir secara spesifik, maka tidak mungkin ada naskh di antara keduanya.

Memaafkan dan bersifat toleran ${ }^{53}$ terhadap ahlu kitab itu diperbolehkan, hingga umat Islam menyampaikan dakwah kepada mereka, dan mereka harus dikenai pajak apabila tidak bersedia memeluk Islam dan membenci perang. Ketika mereka membayar pajak dan hidup di antara kaum muslim dan nampak ada kesalahan atau penyimpangan dari mereka, maka memaafkan dan mengampuni mereka juga wajib, karena perlakuan yang baik dapat menumbuhkan rasa senang dan simpatik mereka pada Islam, dan membalas keburukan dengan kebaikan akan membuat musuh bisa jadi teman. Pandangan ini juga dikuatkan oleh makna al-'Ankabūt: 46 yang artinya "dan janganlah kalian saling mendebat (membantah) ahlu kitab kecuali dengan jawaban atau bantahan yang lebih baik, kecuali orang-orang yang aniaya dari mereka".54

Al-Saqa lebih lanjut menyatakan bahwa al-Baqarah: 190-195, terutama potongan ayat "fa in intahaw fa innallāh ghafür rahịm" merupakan ayat-ayat muhkamah yang tidak bisa di-naskh secara mutlak. Runtutan ayat ini menjelaskan bahwa Allah memerintahkan umat Islam untuk memerangi orangorang yang memusuhi mereka dan tidak memerintahkan untuk bertindak memusuhi orang yang berdamai dengan mereka, baik dengan membunuhnya

51Zaid, 513.

52"fa'fū wa isfahū hattā ya'tiya Allāh bi amrih, inna Allāh 'alā kulli syai' qadīr".

53Toleransi beragama, menurut Schuon seperti dikutip Zainul Bahri dalam artikelnya, pada level eksoterik bisa berwujud dialog, pembicaraan, atau diplomasi berdasarkan rasa hormat satu sama lain, namun bukan kesatuan. Sementara, pada level esoterik ia bisa termanifestasikan dalam pemahaman dan kesadaran tentang kesatuan agama-agama. Lihat: Media Zainul Bahri, "Esoterisme dan Kesatuan Agama-Agama”, Titik Temu Jurnal Dialog Peradaban 2, no. 1 (2009), 121.

${ }^{54}$ Ahmad Hijazi al-Saqa, Lā Naskh fi al-Qur'ān (Kaero-Mesir: Dar al-Fikr al-'Arabi, 1978), 46-47. 
atau menyita hartanya. Allah. mengingatkan agar umat Islam hanya memerangi orang-orang yang memerangi mereka dan juga orang-orang yang menghalanghalangi atau mencegah jalannya syiar Islam..$^{55}$

Al-Saqa juga membantah adanya naskh pada al-Baqarah: 256. Ayat ini memberi pengertian bahwa Allah tidak memperbolehkan perintah untuk beriman dengan paksaan dan kekerasan, melainkan dengan cara yang persuasif dan demokratis (ikhtiari), karena sudah sangat jelas perbedaan antara keimanan dan kekufuran atau petunjuk dan kesesatan dengan dalil dan bukti yang konkrit, sehingga orang yang mengingkari syaitan dan berhala berarti telah berpegang pada tali Allah yang paling kuat yang tidak akan pernah terputus. Sebab itulah, ayat tersebut tidak di-naskh (mansūkhah) oleh ayat perang. Ayat ini tidak hanya berlaku khusus pada ahli kitab, namun juga pada lainnya. Karena kewajiban umat Islam adalah hanya mengajak ahlu kitab dan orang-orang musyrik agar berkenan memeluk Islam. Apabila mereka enggan memeluk Islam maka mereka bebas memeluk agama dan keyakinan mereka selama mereka jauh dari menyakiti orang-orang muslim dan menghalangi dakwah Islam. ${ }^{56}$

Ketiadaan naskh juga dinyatakan pada Āli 'Imrān: 20. ${ }^{57}$ Ayat ini dalam pandangan al-Saqa mengajarkan bahwa dakwah Islam itu memberikan petunjuk, ketika dakwah itu telah disampaikan, sementara mereka tidak bersedia memeluk Islam dan suka hidup berdamai dengan memberikan pajak dari ahlu kitab atau berdamai saja dari kalangan umat lainnya dan juga tidak mencegah orang lain masuk Islam, maka memerangi mereka tidaklah diperbolehkan. Perang hanya ditujukan kepada mereka yang menentang dan memusuhi Islam dan umat Islam atau mencegah orang lain untuk mendapatkan petunjuk Islam setelah petunjuk itu datang pada mereka. ${ }^{58}$

Pandangan yang cenderung menolak eksistensi naskh juga dikemukakan Yusuf Qardhawi.59 Ia tidak sepenuhnya menyetujui adanya klaim naskh dalam

\footnotetext{
55 al-Saqa, 65.

56al-Saqa, 95-96.

57 “wa in tawallah fa innamā 'alaik al-balāgh, wallāh bașīr bi al-'ibād”'.

58al-Saqa, Lā Naskh fi al-Qur'ān, 98.
}

${ }^{59}$ Yusuf Qardhawi lahir Shafth Turab Mesir, 9 September 1926. Ia belajar di Ma'had Thantha, lalu melanjutkan studinya di Fakultas Ushuluddin Universitas al-Azhar hingga selesai 1952. Ia memperoleh gelar Doktor pada 1972 dengan Disertasi yang berjudul “ Zakat dan Dampaknya dalam Penangulangan Kemiskinan”. Ia dikenal sebagai intelektual Islam yang unik dan istimewa karena 
al-Qur'an. Bahkan beliau menyatakan: "kami cukup mengatakan bahwa ayat yang menjadi sandaran orang-orang yang mengatakan adanya naskh bukanlah dilālah qath'i berdasarkan perkataan mereka sendiri. Sebab, perkataan mereka bahwa pemutusan hukum suatu ayat atau lebih dari al-Qur'an termasuk hal penting yang memerlukan dalil qath'i yang bisa dijadikan sandaran. Jika tidak perlu kepada dalil pasti, pada dasarnya ayat-ayat dalam al-Qur'an bersifat muhkamāt, mengikat dan tetap berlaku hingga hari kiamat. Akan tetapi seseorang bisa menjadikan ayat tersebut sebagai dalil menghapus sesuatu yang sudah tetap pada syariat yang lalu atas pilihannya sendiri.60 Dalam hal ini, Qardhawi tidak sependapat dengan pihak yang mengklaim bahwa ayat damai berstatus mansūkhah dengan ayat saif. ${ }^{61}$ Dalam kaitannya dengan kebebasan beragama, Qardhawi berpandangan bahwa orang yang mau membaca teks-teks dalam al-Qur'an, akan menemukan bahwa al-Qur'an jelas menolak pemaksaan dalam beragama. ${ }^{62}$

Ragam pandangan tentang status naskh ayat-ayat toleran (ayat al-'afw wa al-safh) oleh ayat-ayat qitäl adalah wajar, mengingat bahwa penentuan naskh pada ayat-ayat al-Qur'an sendiri tidak mutlak berdasarkan keterangan Nabi saw (ma'tsūrah), melainkan juga melibatkan kemampuan logika akal yang cukup dominan dalam memahami dan menganalisisnya sesuai dengan kriteria-kriteria naskh yang ditetapkan ulama. Pemikiran setiap penafsir tidak dapat dipisahkan dari pengetahuan, khazanah pemikiran dan kecenderungan mainstream yang melingkupi kehidupan mereka masing-masing, sehingga keragaman pemikiran tentang konsep naskh dapat terjadi di kalangan mereka.

\section{E. Refleksi Kritis}

Dua model penafsiran terhadap ayat-ayat toleran dan ayat-ayat qitāl nampak bertentangan sekalipun keduanya sama-sama berpijak atas analisis

memiliki metodologi yang khas dalam menyampaikan risalah Islam. Karena itu, ia diterima oleh banyak kalangan, termasuk Barat sebagai seorang pemikir yang menampilkan Islam secara ramah, santun dan moderat, sekalipun ia berafiliasi dengan Ikhwanul Muslimin di Mesir. Yusuf Qardhawi, Fiqih Jihad; Sebuah Karya Monumental Terlengkap tentang Jihad Menurut al-Qur'an dan Sunnah, diterjemahkan oleh Irfan Maulana Hakim dkk., dari Fiqh al-jihād; Dirāsah Muqāranah li Ahkāmih wa Falsafatih fi Dhau'al-Qur'ān wa al-Sunnah (Bandung: Penerbit Mizan, 2010), xxvii-xxviii.

${ }^{60}$ Qardhawi, Fiqih Jihad, 208.

61 Trigiatno, "Penyelesaian Ayat-ayat Damai dan Ayat Pedang”, 198.

${ }^{62}$ Qardhawi, Fiqih Jihad, 362. 
semantik maupun historis. Pandangan pertama yang mengakui naskh ayat-ayat toleran oleh ayat-ayat qitāl menegaskan bahwa memerangi orang-orang musyrik secara totalitas ( $k a \overline{f f f a h}$ ) diperintahkan sehingga mereka mau menerima Islam dan hingga agama hanya milik Allah Swt., ketika umat Islam secara politik dan sosial dominan. Argumentasi disyariatkannya perang secara totalitas ini didasarkan atas ketiga ayat perang yang diturunkan secara tidak bersamaan itu. Dengan demikian, perang ofensif dalam hal ini bisa dilakukan untuk kepentingan dakwah Islam.

Pandangan kedua menegaskan bahwa ayat-ayat toleran dan ayat-ayat qitāl berlaku semua sesuai dengan konteksnya masing-masing. Ayat-ayat toleran terus berlaku hingga sekarang sebagai aplikasi praktis dari sikap menghargai kebebasan beragama dalam Islam. Sementara perintah berperang terhadap orang-orang musyrik hanya berlaku terhadap kalangan mereka yang memiliki karakter khusus, yakni memusuhi serta bermaksud konfrontasi dengan umat Islam, dan tidak berlaku bagi orang-orang non-muslim yang bersedia hidup berdampingan secara damai dengan umat Islam. Dengan begitu, perang dalam hal ini bersifat defensif, yakni sebagai bentuk pertahanan atau pembelaan diri yang wajib dilakukan atas segala bentuk agresi orang-orang musyrik terhadap umat Islam, dan pencegahannya atas akses dakwah Islam ke dalam masyarakat.

Kedua pandangan dan penafsiran para ulama tersebut apabila dilihat secara hermeneutik-kritis, ${ }^{63}$ maka tidak dapat dilepaskan dari pengaruh ideologi yang melingkupi kehidupan masing-masing ulama itu. Ulama seperti Ibn Sallāmah yang hidup pada abad ke-4 H. dan al-Shami (w. 942 H.) yang hidup pada abad ke-9 H. memiliki penafsiran yang mengakui naskh ayat-ayat toleran oleh ayat al-saif. Mereka membenarkan perang ofensif umat Islam dalam menebarkan dakwah Islam di muka bumi, terutama di saat umat Islam telah dominan secara politik maupun sosial dan hal ini dianggap sebagai makna yang ideal. Bersabar dan memaafkan hanyalah merupakan tindakan tentatif (realistis) yang tidak ideal dan penuh dengan keterpaksaan karena ketidak-

\footnotetext{
${ }^{63}$ Hermeneutika kritis Habermas bertujuan untuk mengungkap kepentingan di balik teks. sebagai problem hermeneutisnya. Kepentingan itu adalah ideologi penafsir, sehingga teks patut dicurigai dan oleh karena itu, hermeneutika ini disebut hermeneutika kecurigaan karena berkepentingan untuk menyingkap kepentingan-kepentingan ideologis di belakang sebuah teks. Lihat: Ilham Saenong, Hermeneutika Pembebasan; Metodologi Tafsir al-Qur'an Menurut Hassan Hanafi (Jakarta: Penerbit Teraju, 2002), 45.
} 
berdayaan umat Islam waktu itu. Sarjana Barat semacam Rudi Paret, sebagaimana dikutip Mun'im Sirry, sepakat dengan asumsi ini. Menurutnya, ayat tentang kebebasan beragama hanyalah ekspresi ketidakberdayaan Islam berhadapan dengan mereka yang bersikukuh dengan keyakinannya dan tidak mau menerima Islam. 64

Pemahaman tersebut, secara historis, dapat dipahami karena abad sebelum renaissance (sebelum abad ke-18) adalah abad dengan sistem politik monarki absolut yang otoriter di mana kebanyakan darinya menyatukan otoritas agama dengan politik, sebagaimana penyatuan politik dengan kekuasaan Gereja atau Kekhalifahan (al-khiläfah), bahkan pemegang kekuasaan seperti raja hampir identik dengan Tuhan yang memiliki kekuasaan penuh atas kerajaan dan rakyatnya. Ideologi monarkhi yang sedang melingkupi kehidupan mereka sangatlah mungkin bisa dipahami apabila mempengaruhi pola penafsiran dan pandangan ulama tersebut tentang ayat-ayat toleran dan ayat qital. Apalagi ideologi tersebut didukung dengan argumentasi naqliyah dan kepentingan dakwah Islam yang sangat mulia.

Sedangkan Abdullah bin Baz sekalipun hidup di era modern di mana ideologi demokrasi dan ideologi global hak azasi manusia (HAM) sudah dikenal, namun ia adalah seorang ulama yang beraliran Wahhabi yang dikenal memiliki karakteristik tekstualis di Saudi Arabia yang masih menganut sistem monarkhi absolut hingga sekarang. Maka sangatlah mungkin kedua ideologi itu sangat berpengaruh terhadap penafsirannya itu.

Berbeda dengan ulama tersebut di atas, intelektual Islam semacam Mustafa Zaid, al-Saqa, dan Yusuf Qardhawi merupakan ulama Mesir dengan sistem pemerintahan semi-presidensial ${ }^{65}$ dan multi partai di era kontemporer, di mana ideologi demokrasi dan ideologi global hak azasi manusia (HAM) sudah sedemikian berkembang menghegemoni. Cara pandang mereka dalam

${ }^{64}$ Mun'im Sirry, "La ikraha fi al-din (tidak ada paksaan dalam agama): Menafsirkan tafsir alQur'an bersama Paul Ricoeur", dalam Syafa'atun al-Mirzanah \& Sahiron Syamsuddin (ed.), Upaya Integrasi Hermeneutika dalam Kajian Qur'an dan Hadits (Teori dan Aplikasi) (Yogyakarta: UIN SUKA, 2011), 73.

${ }^{65}$ Mesir adalah negara dengan sistem semipresidensial multipartai. Secara teoritik, kekuasaan eksekutif dibagi bersama antara presiden dan perdana menteri, namun dalam prakteknya kekuasaan justru terpusat pada presiden, yang selama ini dipilih dalam pemilu dengan kandidat tunggal. Mesir juga melaksanakan pemilu parlemen multi partai (Saripedia.Com). 
penafsiran tersebut, sedikit atau banyak, dan sadar atau tidak sadar ikut dipengaruhi oleh ideologi-ideologi tersebut.

Dengan demikian, terdapat logika yang berbeda di antara kedua pandangan tersebut. Ulama yang membenarkan naskh ayat-ayat toleran berkeyakinan bahwa perang ofensif terhadap orang-orang musyrik dalam menebarkan dakwah Islam di muka bumi sewaktu umat Islam dominan secara politik maupun sosial merupakan makna ideal atau tuntutan ideal Islam. Bersabar dan memaafkan mereka hanyalah merupakan tindakan tentatif (realistis-tentatif) dan tidak ideal yang penuh keterpaksaan karena ketidakperdayaan umat Islam waktu itu. Sebaliknya, ulama yang menyatakan berlakunya ayat-ayat toleran secara muhkan -meminjam analisis al-Na'imberkeyakinan bahwa ayat-ayat toleran dan penuh kedamaian yang Makkiyah itu justru merupakan tuntutan dan makna idealitas dalam Islam.

Perintah perang yang ada waktu itu hanyalah merupakan makna atau tuntutan realistik yang penuh keterpaksaan sebagai cara terakhir untuk mempertahankan eksistensi Islam dan umatnya, karena kondisi umat Islam waktu itu yang lemah secara politik dan sosial, yang dipaksa berperang oleh para penentang Islam waktu itu. Kondisi masa itu belum memungkinkan diberlakukannya ayat-ayat toleran dan damai secara käffah, sehingga harus ada penundaan sampai kondisi umat Islam siap dan memungkinkan untuk menerapkannya. Beberapa sarjana Barat mendukung pandangan ini. Michael Cook, sebagaimana dikutip Sirry, mengakui bahwa ayat tentang toleransi memberikan penegasan kuat bahwa agama yang benar (Islam) bisa hidup berdampingan dengan segala bentuk agama yang salah. Yohanan Friedmann menyatakan bahwa al-Qur'an 2: 256 telah menjadi locus classicus bagi diskusi toleransi agama dalam Islam. Berdasarkan ayat itu, Bernard Lewis menyangkal pandangan bahwa Islam disebarkan dengan penaklukan militer. Sepanjang sejarah perkembangan Islam, kaum muslim Arab menaklukkan berbagai wilayah bukan karena motivasi keagamaan, melainkan lebih karena haus kekuasaan dan ke-Arab-an [arabic culture]. ${ }^{66}$

\footnotetext{
66Sirry, "La ikraha fi al-din,” 72.
} 


\section{F. Kesimpulan}

Dari kajian yang telah dipaparkan di atas dapat ditarik beberapa kesimpulan. Pertama, terdapat sejumlah ayat toleran dalam al-Qur'an pada satu sisi, namun pada sisi lain di dalamnya ada juga ayat-ayat yang berisi perintah perang kepada orang-orang musyrik. Ayat-ayat toleran diklaim berjumlah 114, dan ada pula yang menyatakan 140 buah ayat. Sedangkan ayat-ayat yang memerintahkan peperangan terhadap orang musyrik berjumlah tidak kurang dari 22 buah ayat.

Kedua, secara teoritis konsep pertentangan dalil (ta'āruḍ al-adillah) telah banyak diperbincangkan dalam ușul fiqh, dan salah satu di antaranya pertentangan ( $t a ' a ̄ r u d ̣$ ) di antara ayat-ayat al-Qur'an atau dualisme ayat al-Qur'an. Karena asumsi adanya pertentangan dalil, para ulama menyepakati teori penyelesaiannya, yang meliputi 4 metode, yakni (1) al-naskh, (2) al-tarjih, (3) aljam' wa al-taufiq, dan (4) tasāqut al-dalilain. Hanya ada sebagian ulama yang lebih mendahulukan metode naskh atas lainnya, dan sebagian yang lain lebih mendahulukan metode kompromi (al-jam' wa al-taufiq) atas lainnya. Atas dasar itulah, al-nāsikh wa al-mansūkh menjadi bagian penting dari cabang 'ulum al-Qur'an.

Ketiga, persepsi tentang adanya dualisme (ta'āruḍ) antara ayat-ayat toleran dengan ayat perang telah menjadi diskursus dalam studi al-Qur'an. Intelektual Islam seperti Ibn Sallamah, al-Shami, dan Abdullah Bin Baz mengakui eksistensi ta'ârudh tersebut, dan sebab itu pula mereka menyatakan bahwa ayat-ayat toleran itu telah di-naskh (mansūkhah) oleh ayat perang atau ayat pedang sebagai cara untuk menyelesaikan pertentangan tersebut. Sementara sebagian intelektual Islam yang lain seperti Mustafa Zaid, Ahmad Hijazi al-Saqa, dan Yusuf Qardhawi menafikan pertentangan tersebut, karena dengan pendekatan tafsir berdasarkan kajian siyāq al-kalām dan munāsabah ayat-ayat tersebut di samping analisis historisitasnya (asbāb al-nuzūl), ayat-ayat tersebut dapat dikompromikan, sehingga dinyatakan berlaku muhkam semua dengan konteksnya masing-masing.] 


\section{DAFTAR PUSTAKA}

'Abd al-Bāqi, Muhammad Fu'ād. al-Mu'jam al-Mufahras li Alfāẓ al-Qur'ān al-Karīm, Kaero: Dār al-Hadīts, 1996.

al-'Alwāni, Taha Jābir. La Ikrāh fi al-Dīn Isykāliyyah al-Riddah wa al-Murtadīn min Sadr al-Islām ilā al-Yaum, Kairo: Maktabah al-Syurūq al-Islāmiyah, 2006.

Arnold, Thomas W. al-Da'wah ilā al-Islām; bahts fi Tarīkh Nasyr al-'Aqīdah alIslāmiyyah (terj), Mesir: Maktabah al-Nahdzah al-Misriyyah, 1970.

Bahri, Media Zainul. "Esoterisme dan Kesatuan Agama-agama”, Titik Temu Jurnal Dialog Peradaban 2 , no. 1 (2009), 117-144.

Chirzin, Muhammad. "Keanekaragaman dalam al-Qur'an", Tsaqafah Jurnal Peradaban Islam 7, no. 1 (2011), 51-68.

Engineer, "Asghar Ali, Islam and Doctrines of Peace and Non-Violence", 2001, International Journal Ihya Ulum al-Din 3, no. 2 (2001) 119-128.

Farih Amin. Analisis Pemikiran Abdullah bin Baz dan Sayyid Muhammad al-Maliky; Mencari Titik Kesepakatan Sunny dan Wahaby Melalui Metodologi Istimbath Hukum Islam, Semarang, LP2M IAIN Walisongo, 2014.

Haroen, Nasrun. Ushul Fiqh cet. 2, Jakarta: Logos Wacana Imu, 1997.

Ibn Sallāmah, Hibbatullāh. al-Nāsikh wa al-Mansūkh fi al-Qur'ān al-Aẓim, Damaskus: al-Yamāmah, 1987.

Khalāf, Abd al-Wahhāb. 'Ilm Ușūl al-Fiqh, Kaero: Dar al-Kutub al-'Ilmiyyah, 1986.

Khotimah, Khusnul. Demokrasi, Monarki dan Republik, 2013. diunduh pada 21 Mei 2013 dari http://white-hollow.blogspot.com/2013/05/demokrasimonarki-dan-republik.html.

Qardhawi, Yusuf. Fiqih Jihad; Sebuah Karya Monumental Terlengkap tentang Jihad Menurut al-Qur'an dan Sunnah, diterjemahkan oleh Irfan Maulana Hakim dkk., dari Fiqh al-Jihād; Dirāsah Muqāranah li Ahkāmih wa Falsafatih fi Dhau'al-Qur'ān wa al-Sunnah. Bandung: Penerbit Mizan, 2010.

al-Qattān, Mannā'. Mabāḥith fi 'Ulūm al-Qur'ān, Beirut: Muassasah al-Risālah, , 1994. 
al-Qur'an dan Terjemahannya, 1418, Madinah: Lembaga Percetakan al-Qur'an Raja Fahd.

Saenong, Ilham. Hermeneutika Pembebasan; Metodologi Tafsir al-Qur'an Menurut Hassan Hanafi, Jakarta: Penerbit Teraju, 2002.

al-Saqa, Hijazi, Ahmad. Lā Naskh fi al-Qur'ān, Kaero-Mesir: Dar al-Fikr al-'Arabi, 1978.

al-Shāmi, Muhammad bin Yusuf al-Ṣāihi. Subul al-Hudā wa al-Rashād fi Sirah khair al-'Ibād, Beirut-Libanon: Dār al-Kutub al-'Ilmiyyah, 1993.

Sirry Mun'im. "La Ikraha fi al-Din (Tidak Ada Paksaan dalam Agama): Menafsirkan Tafsir al-Qur'an Bersama Paul Ricoeur", dalam Syafa'atun alMirzanah \& Sahiron Syamsuddin (ed.), Upaya Integrasi Hermeneutika dalam Kajian Qur'an dan Hadits (Teori dan Aplikasi), Yogyakarta, UIN SUKA, 2011.

Sumbulah, Umi. Konfigurasi Fundamentalisme Islam, Malang: UIN Press, 2009.

al-Suyūti, Jalāl al-Dīn 'Abd al-Raḥmān bin Abi Bakr, Țabaqāt al-Mufassirīn, Beirut Libanon: Dār al-Kutub al-Ilmiyyah, t.th.

Syarifuddin, Amir. Ushul Fiqh I, cet. I, Jakarta: Logos Wacana Ilmu, 1997.

Trigiatno, Ali. "Penyelesaian Ayat-Ayat Damai dan Ayat Pedang dalam al-Qur'an", Jurnal Penelitian STAIN Pekalongan 9, no. 2 (2012), 264-282.

Zaid, Musțafa. al-Naskh fi al-Qur'ān al-'Adzīm; Dirāsah Tashrīìyyah Tarikhiyah Naqdiyah, Mesir: Dar al-Wafa, 1987.

al-Zuhalī, Wahbah. Ușūl al-Fiquh al-Islāmi, Beirut: Dār al-Fikr, 1986. 